\title{
Stability Of Spirulina platensis Ice Cream and Shelf Life Prediction Using Accelerated Shelf Life Test Method Based On Physical and Antioxidant Analysis
}

\author{
Salsabila Noorannisa and Nurfitri Ekantari* \\ Department of Fisheries, Faculty of Agriculture, Universitas Gadjah Mada, Yogyakarta
}

\begin{abstract}
The purpose of this research was to know the stability and shelf life of $S$. platensis ice cream during storage. For a storage period of two months the samples were stored at -15 for the first month and $10^{\circ} \mathrm{C}$ for the next month. Percentage of DPPH and emulsion stability were observed during storage in two replicates. The stability of emulsion slightly decreased along the period of storage. At the beginning of -15 ${ }^{\circ} \mathrm{C}$ storage, stability of emulsion was $98 \%$, and at the end of storage was $93 \%$. At $-10{ }^{\circ} \mathrm{C}$, the stability of emulsion decreased from $91 \%$ to $86 \%$. At $-5{ }^{\circ} \mathrm{C}$, the stability of emulsion decreased from $86 \%$ to $82 \%$. Longer storage decreased the quality of the ice cream texture and antioxidant content. In three months storage, antioxidant reduced around $56.91 \%$. Increased in temperature storage showed greater impact on the reduction of texture quality of $S$. platensis ice cream. The ASLT analysis on selected parameter shows that spirulina ice cream have shelf life of 25,24 , and 21 days in temperature $-15,-10$, and $-5^{\circ} \mathrm{C}$, respectively. Future development was required in measuring the relationship between instrument and sensory analysis of the ice cream.
\end{abstract}

\section{Introduction}

S. platensis is a planktonic microalgae belonging to the cyanobacterium group, filamentous, growing in tropical and subtropical waters. S. platensis can be found in fresh and marine waters, living in alkaline environments [10]. This microalgae is one of the most potential natural food sources for both animals and humans. Its high protein content reaches $60-70 \%$ (dry basis) [4]. In dry state $S$. platensis contains a protein consisting of amino acids such as serine, glycine, arginine, trionin, alanine, tyrosine, valine, methionine, cystine, isoleucine, leucine, and phenylalanine [20]. S. platensis also contains natural pigments in the form of beta carotene, chlorophyll, xanthophyll, ficocyanin, so that it functions as a source of antioxidants. Antioxidant compounds prevent cancer and free radicals, improve the body's immune system, and reduce cholesterol levels [6].

S. platensis is widely used for food and non-food industries. In non-food industry, S. platensis is used as drugs and supplements. As a supplement, $S$. platensis served as natural source of antioxidant. The bioactive compounds contained in $S$. platensis include phycocyanin which has been known to increase the immune system and also plays an important role as antioxidants, anti-inflammatory, and neuroprotective. Treatment of C-ficocyanin from S. platensis $(75 \mathrm{mg} / \mathrm{kg}$ body weight) showed antioxidant activity and reduced oxidative stress in mice [14]. Apart from being an antioxidant, spirulina can also be used as an anti-diabetic agent. The bloo*d glucose level in the body decreased due to the content of gamma linoleic fatty acids and antioxidants in S. platensis which further regulated fat metabolism and increased insulin response [12]. S. platensis can be added to food products such as noodles [19], sweet bread [22], cookies [21], chocolate bars [15], crakers [17], fresh bread [18], and ice cream [13,11] in order to increase the nutritional value.

One of disanvantages of algae, that is cannot be processed at higher temperatures or the nutritional value will decrease. S. platensis fortification in low temperature product will mantain the nutritional value. One of the food product that can be fortified with Spirulina platensis is ice cream. Ice cream is people's favorite dessert because it has a soft texture and gives cold sensation in the mouth. In general, ice cream has an expired date of 12-24 months, however, it is usually withdrawn after 1-3 months storage. This is due to the formation of large ice crystals through the recrystallization process which causes the rough texture of the ice cream. Sensory signs of quality reduction of an ice cream can be identified through the formation of ice crystals, sandy textures, lost of flavor, and unstable emulsion system [7]. Recrystallization is the result of fluctuations in storage temperatures which causes some ice crystals to melt and form new larger crystals [5].

Several methods of determining shelf life in food products has been developed, such as Extended Storage Studies (ESS) and Accelerated Shelf Life Testing (ASLT). ESS determine the expiration date by storing the product in the actual

${ }^{*}$ Corresponding author: nurfitri.ekantari@gmail.com 
conditions. This method produces the most appropriate results, but takes a long time and costs a lot. In ASLT, shelf life of a product is determined by storing the product in an environment that causes rapid damage, such as at high temperature or humidity. Data on quality change during storage is converted in the form of mathematical models, then shelf life is determined by extrapolarizing equations under normal storage conditions. This method requires a shorter time with a good level of accuracy [9].

The determination of frozen products shelf life using the ASLT method is done by storing products at temperatures above the normal storage temperature to find the kinetics of product damage [25]. Temperature is used as a treatment in the shelf life testing of ice cream because temperature is a critical factor that cause damage to ice cream. The temperature of $-15,-10$, and $-5^{\circ} \mathrm{C}$ was used in a storage experiment to determine ice cream shelf life [2].

$S$. platensis ice cream is a high antioxidant product. On the previous research, S. platensis ice cream formulation has been found with the use of cinnamon as a masking agent and gelatin as a stabilizer that is favored by panelists [11]. Through this research, the shelf life of the ice cream was determined with the Accelerated Shelf Life Testing method with the Arrhenius approach.

\section{Materials and methods}

\subsection{Ice cream production}

The production of ice cream started with mixing fresh cow's milk, skim milk, sugar, and gelatin. After that, S.platensis powder and cinnamon powder were added and homogenized. And then, the mixture was stored in refrigerator for aging process in $4^{\circ} \mathrm{C}$ for 24 hours. After that, the mixture were homogenized 4 times, and then the ice cream mixture can be stored at temperature of $-15,-10$, and $-5^{\circ} \mathrm{C}$ for three months respectively.

\subsection{Physical analysis [1]}

Ice cream sample of 5 gram was incubated in oven with a temperature of $45^{\circ} \mathrm{C}$ for 1 hour then kept in a coolant below $0^{\circ} \mathrm{C}$ for 1 hour. Then, the sample was re-incubated in the oven at $45^{\circ} \mathrm{C}$ for 1 hour. Emulsion stability was calculated based on the percentage of the separate phase of the overall emulsion using the following formula:

Emulsion Stability $(\%)=\frac{\text { Remaining phase weight }}{\text { Total weight of the emulsion materials }} \times 100 \%$

Informations:

The remaining phase weight $=($ weight of the second oven emulsion + cup $)-$ weight of the cup

The total weight of the emulsion material $=($ weight of the emulsion + cup $)-$ weight of the cup

\subsection{Antioxidant analysis [16, 24]}

A total of 100 microlitre of ice cream sample was dissolved with $1 \mathrm{ml}$ methanol solvent, then 700 microlitre DPPH solution was added. Samples were incubated for 15 minutes in a dark room, and centrifuged at 3000 rpm for 10 minutes. The supernatant was taken for testing with a wavelength of $515 \mathrm{~nm}$ with a spectrophotometer. Control was made with DPPH and methanol solutions. Percentage of inhibition was calculated by the following formula:

$\% D P P H=\left[\frac{(\text { Abs515nm control }- \text { Abs515nm Sample })}{(\text { Abs515nm control })}\right] \times 100$

\subsection{Accelerated shelf life test (ASLT)}

Accelerated shelf life test is an approach to determining the shelf life of food product by storing product in the environment that can accelerate the decline in product quality. Data changed in product quality are made over time. The first data is done by making a graph between quality changes with time. The linear regression equation $(y=a+b x)$, where $y$ is the change in product quality, $\mathrm{a}$ is the initial product quality value, and $\mathrm{b}$ is obtained from the slope or can be called $\mathrm{k}$ is the rate of change in product quality. The order of reaction determined by making a graph. For the zero order graph is made by plotting the value of $\mathrm{k}$ with storage time. The graph of decreasing quality parameters for zero order is a consant decrease in quality and can be illustrated by the equation: At - A0 = kt, where At is the value of quality parameter at time, $\mathrm{A} 0$ is an initial value of quality parameter $\mathrm{A}, \mathrm{k}$ is a rate of change in quality, and t means storage time. And the other side, the first order graph is made by plotting the value on Ln with storage time. By choosing the most influential reaction order by looking at the value of $\mathrm{R}^{2}$, the largest value is taken. After that, graph the corelation of the rate of decline in product quality to storage temperature by using an approach Arrhenius, and create the linear regression equation with the equation $\mathrm{Ln} \mathrm{k}=\mathrm{Ln} \mathrm{k} 0-(\mathrm{E} / \mathrm{R})(1 / \mathrm{T})$, where Ln $\mathrm{k} 0$ is intercept, E/R is slope, E is activation energy, $\mathrm{R}$ means ideal gas constant. After that, the Arrhenius constant is calculated using equation $\mathrm{k}=\mathrm{k} 0$. e $-\mathrm{E} / \mathrm{RT}$. And then calculate the parameters that 
most affect the decline in product quality by looking at the parameters that have the lowest active energy value. After know the most affect parameter, and then calculate the shelf life estimation with equation ts $=\ln (\mathrm{N} 0-\mathrm{Nt}) / \mathrm{k}$, for the first order reaction rate. And the other hand, for the zero order reaction rate using equation ts $=(\mathrm{N} 0-\mathrm{Nt}) / \mathrm{k}$. From the reaction rate equation could be predict the shelf life time value for particular storage temperature. While, it can also predict the shelf life using the Q10 equation. Estimation of shelf life using the Q10 method is done by involving the value of active energy. Q10 value can explain that the value of the rate of chemical reactions will multiply with an increase in temperature of $10^{\circ} \mathrm{C}$.

\section{Results and discussion}

\subsection{Emulsion stability}

Protein polymers in ice cream emulsion system will contact the surface of the fat globule, the hydrophobic side will absorbed on the surface, while the hydrophilic side will expand to the serum phase. The proportion of absorbed and distributed parts will determine the function of polymer proteins and produce emulsion stability [8]. Ice cream consists of small globules of fat that suspended in water. These globules cannot be attract because each globules surrounded by a protein membrane that attracts water, and the water keeps each globula away. Stirring will damage the protein membrane which makes the fat get closer to each other and as a result the cream mixture will rise to the surface or resulted as separated mixture. This problem can be solved by adding an emulsifier to the ice cream mixture. Emulsifier molecules will replace membrane proteins, one end of the molecule will dissolve in water, while the other end will dissolve in fat [8]. On this ice cream formulation is not used in addition of any emulsifier, so that ice cream resulted in two separate layers. The results of testing the emulsion stability on spirulina ice cream are shown in Table 1.

Table 1. Emulsion stability during storage

\begin{tabular}{|c|c|c|c|c|}
\hline Temperature & Days & Emulsion stability (\%) & $\mathrm{R}^{2} 0$ Order & $\mathrm{R}^{2}$ 1st Order \\
\hline \multirow{6}{*}{$-15^{\circ} \mathrm{C}$} & 0 & $98.81 \%$ & \multirow{6}{*}{0.900} & \multirow{6}{*}{0.895} \\
\hline & 6 & $98.15 \%$ & & \\
\hline & 12 & $97.49 \%$ & & \\
\hline & 18 & $96.98 \%$ & & \\
\hline & 24 & $95.51 \%$ & & \\
\hline & 30 & $93.04 \%$ & & \\
\hline \multirow{6}{*}{$-10^{\circ} \mathrm{C}$} & 0 & $91.83 \%$ & \multirow{6}{*}{0.874} & \multirow{6}{*}{0.876} \\
\hline & 5 & $90.65 \%$ & & \\
\hline & 10 & $88.00 \%$ & & \\
\hline & 15 & $87.41 \%$ & & \\
\hline & 20 & $86.52 \%$ & & \\
\hline & 25 & $86.73 \%$ & & \\
\hline \multirow{6}{*}{$-5^{\circ} \mathrm{C}$} & 0 & $86.38 \%$ & \multirow{6}{*}{0.713} & \multirow{6}{*}{0.712} \\
\hline & 4 & $87.03 \%$ & & \\
\hline & 8 & $86.78 \%$ & & \\
\hline & 12 & $86.39 \%$ & & \\
\hline & 16 & $83.67 \%$ & & \\
\hline & 20 & $82.15 \%$ & & \\
\hline \multicolumn{3}{|c|}{ Average } & 0.829 & 0.828 \\
\hline
\end{tabular}

Emulsifiers are compounds that have surface activity or surface active agents, which can reduce surface tension or surface tension in both fluids with different polarity, resulted in good mixture homogeneous ice cream. The surface activity of the emulsifier works through the hydrophilic side of the head that is attracted to the water phase and the lipophilic side of the tail is in the oil phase [23]. There are several factors that can affect the stability of the emulsion, there are process of homogenization of materials, and temperature. The high speed homogenization process will produce a more stable emulsion system, this is because the homogenization process is able to break down fat globules into smaller ones, so that the distribution of fat globules is more evenly distributed and small size. The smaller fat globules will make 
it easier for the fat globule to bind to the same level of polarity. The next factor is temperature. Rising temperatures will cause the emulsion to separate into two layers causing the emulsion system to be unstable [23]

\subsection{Antioxidant analysis}

Based on the results of the study in Table 2, it can be seen that along with storage time the percentage of inhibition decreased. Along with storage, antioxidants have decreased due to several factors such as exposure to light, thermal shock or unstable freezer temperatures. Another factor that causes decreased antioxidants is the storage of ice cream at extreme temperatures can cause the content of milk in the ice cream to become acidic. The source of sour taste comes from lactic acid bacteria fermentation. These bacteria will degrade antioxidant compounds in the product. A decrease in antioxidant activity during cold storage is caused by an increase in degradation of phenolic compounds with antioxidant activity [3].

Table 2. Percentage of inhibition DPPH during storage

\begin{tabular}{|c|c|c|c|c|}
\hline Temperature & Days & $\%$ inhibition of DPPH & $\mathrm{R}^{2} 0$ Order & $\mathrm{R}^{2} 1$ st Order \\
\hline \multirow{6}{*}{$-15^{\circ} \mathrm{C}$} & 0 & 98.82 & \multirow{6}{*}{0.964} & \multirow{6}{*}{0.965} \\
\hline & 6 & 98.62 & & \\
\hline & 12 & 98.52 & & \\
\hline & 18 & 98.25 & & \\
\hline & 24 & 98.16 & & \\
\hline & 30 & 98.10 & & \\
\hline \multirow{6}{*}{$-10^{\circ} \mathrm{C}$} & 0 & 96.37 & \multirow{6}{*}{0.862} & \multirow{6}{*}{0.866} \\
\hline & 5 & 93.56 & & \\
\hline & 10 & 92.63 & & \\
\hline & 15 & 91.18 & & \\
\hline & 20 & 90.86 & & \\
\hline & 25 & 90.72 & & \\
\hline \multirow{6}{*}{$-5^{\circ} \mathrm{C}$} & 0 & 64.29 & \multirow{6}{*}{0.983} & \multirow{6}{*}{0.992} \\
\hline & 4 & 58.73 & & \\
\hline & 8 & 53.55 & & \\
\hline & 12 & 48.32 & & \\
\hline & 16 & 46.38 & & \\
\hline & 20 & 41.90 & & \\
\hline \multicolumn{3}{|c|}{ Average } & 0.936 & 0.941 \\
\hline
\end{tabular}

\subsection{Shelf life analysis}

Based on the calculation results of $\mathrm{R}^{2}$, it shows that the antioxidant parameter has the highest $\mathrm{R}^{2}$ value, so that the parameter is used to estimate the shelf life of spirulina ice cream. Parameters with large $\mathrm{R}^{2}$ values indicate that these parameters occur the fastest quality quality during ice cream storage and are very sensitive to storage temperature. Calculation of shelf life of spirulina ice cream is done by looking for the value of the linear regression equation between the storage time and the storage temperature of the parameters tested. The linear regression equation of the antioxidant parameter can be seen in Table 3 . The sensory parameters of antioxidant should be 1 st order because they show $\mathrm{R}^{2}$ results greater zero order. So the regression equation is used in Table 4.

Table 3. Regression equation and critical parameter order determination

\begin{tabular}{|c|c|c|c|c|}
\hline \multirow{2}{*}{ Temperature $\left({ }^{\circ} \mathrm{C}\right)$} & \multicolumn{2}{|c|}{ Regression equation } & \multicolumn{2}{|c|}{$\mathrm{R}^{2}$} \\
\hline & 0 order & 1st order & 0 order & 1st order \\
\hline-15 & $-0.025 x+98,789$ & $-0.0003 x+4,593$ & 0.9645 & 0.9646 \\
\hline-10 & $-0.2159 x+95,257$ & $-0.0023 x+4,5566$ & 0.8616 & 0.8664 \\
\hline-5 & $-1.1015 x+63,215$ & $-0.0211 x+4,1554$ & 0.9831 & 0.9915 \\
\hline \multicolumn{3}{|c|}{ Average } & 0.9364 & 0.94083 \\
\hline
\end{tabular}


Table 4. Regression equation based on selected parameter

\begin{tabular}{|c|c|}
\hline \multirow{2}{*}{ Temperature $\left({ }^{\circ} \mathrm{C}\right)$} & Regression equation \\
\cline { 2 - 2 } & $1^{\text {st }}$ order \\
\hline-15 & $-0.0003 \mathrm{x}+4.593$ \\
\hline-10 & $-0.0023 \mathrm{x}+4.5566$ \\
\hline-5 & $-0.0211 \mathrm{x}+4.1554$ \\
\hline
\end{tabular}

Determination of shelf life of Spirulina platensis ice cream was calculated by linear regression equation of the parameters which had the highest $\mathrm{R}^{2}$ and the lowest activation energy. From the equation, the $\mathrm{k}$ value can be used to calculate shelf life. The value of $k$ is obtained from $\ln k=\ln k o-(E a / R)(1 / T)$, where ln ko = intercept, Ea / R = slope. Then the obtained $\mathrm{k}$ value is entered into the reaction kinetics equation based on the chosen reaction order. Paraneter antioxidant follows first order, so the shelf life equation is $\mathrm{Ln} \mathrm{Nt}=\mathrm{Ln} \mathrm{No}+\mathrm{k}$.ts. The calculation of Arrhenius parameters is done by calculating the values of $\mathrm{k}$ and $\mathrm{ln}$ can be seen in Table 5, obtained by the regression equation $\mathrm{y}=\mathrm{bx}+\mathrm{a}$.

Table 5. Calculation of Arrhenius equations

\begin{tabular}{|c|c|c|c|c|c|}
\hline Temperature $\left({ }^{\circ} \mathrm{C}\right)$ & $1 / \mathrm{T}(\mathrm{K})$ & Regression equation & $\mathrm{a}$ & $\mathrm{b}=\mathrm{k}$ & $\mathrm{Ln} \mathrm{b}=\mathrm{Ln} \mathrm{k}$ \\
\hline-15 & 0.0038 & $-0.0003 \mathrm{x}+4.593$ & 4.593 & 0.0003 & -8.111 \\
\hline-10 & 0.0038 & $-0.0023 \mathrm{x}+4.5566$ & 4.556 & 0.0023 & -6.074 \\
\hline-5 & 0.0037 & $-0.0211 \mathrm{x}+4.1554$ & 4.155 & 0.0211 & -3.858 \\
\hline
\end{tabular}

Note: $\mathrm{a}=$ intercept $\mathrm{b}=\mathrm{k}=$ slope $=$ Arrhenius constant

\section{I/T VS Ln K}

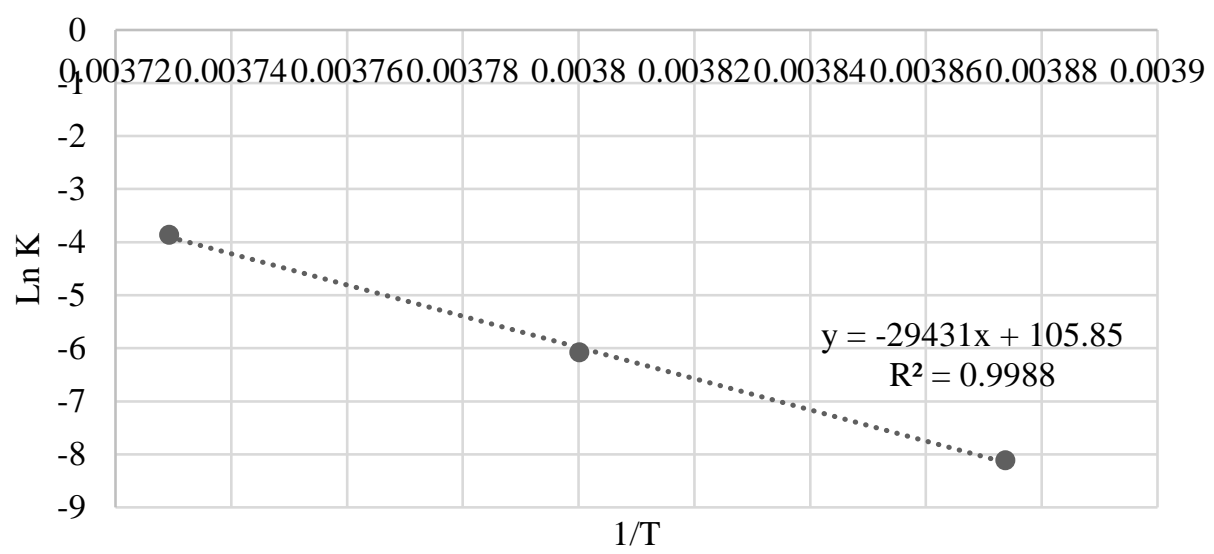

Fig. 1. 1/T vs Ln K

Based on the graph in Figure 1, the value of slope is -29431 and intercept 105,85 . Then calculate the Arrhenius constant $(\mathrm{k})$. From the graph of the correlation of $\ln \mathrm{k}(\mathrm{y})$ to $1 / \mathrm{T}(\mathrm{x})$, the equation $\mathrm{y}=-29431 \mathrm{x}+105,85$ is obtained and it is compared with the Arrhenius equation namely Ln k = Ln k0 - Ea / RT, where the value of Ln k0 = 105,85 and Ea / $\mathrm{R}=29431$, by substituting the temperature value in the Arrhenius equation, $\mathrm{k}$ can be obtained for several temperatures:

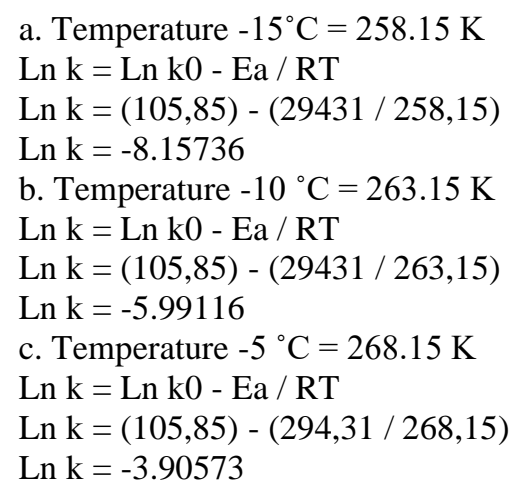


Table 6 shows that the shelf life of spirulina ice cream at temperatures of $-15,-10$, and $-5^{\circ} \mathrm{C}$ were 25 days, 24 days and 21 days respectively. In this calculation a calculation with the rate of the first order is used, namely the equation ts $=(\mathrm{Ln}$ No - Ln Nt) / $\mathrm{k}$. Used in 1st order because it has the highest $\mathrm{R}^{2}$, which is 0.94 .

Table 6. Calculation of shelf life

\begin{tabular}{|c|c|c|c|c|c|c|c|}
\hline $\mathrm{T}$ & $\mathrm{k}$ & $\mathrm{No}$ & $\mathrm{Nt}$ & Ln No & Ln Nt & Ln No-Ln Nt & ts (days) \\
\hline-15 & 0,000287 & 98.82019 & 98.103 & 4.593302 & 4.586021 & 0007280481 & 25.40133 \\
\hline-10 & 0,002501 & 96.37097 & 90.726 & 4.568205 & 4.507842 & 0.06036315 & 24.13779 \\
\hline-5 & 0,020126 & 64.292 & 41.906 & 4.163437 & 3.73542 & 0.428017156 & 21.26668 \\
\hline
\end{tabular}

In addition to using the Arrhenius equation, estimation of shelf life can also be done using the equation Q10. The Q10 value can explain that the rate of the chemical reaction will multiply in the presence of an increase in temperature of $10^{\circ} \mathrm{C}$. Estimation of shelf life using the Q10 method is done using the Ea value or activation energy. The calculation of the Q10 value is as follows:

a. Calculate the value of Ea

If the value of $\mathrm{Ea} / \mathrm{R}=29431$, then the Ea value for $\mathrm{R}=1.986 \mathrm{kal} / \mathrm{molK}$ is

$\mathrm{Ea}=29431 \times 1.986 \mathrm{kal} / \mathrm{molK}$

$\mathrm{Ea}=58449,966$

b. Determination of Q10 at temperatures of -15 to $-5^{\circ} \mathrm{C}$

$\mathrm{Q}_{10}=e^{E a(T 2-T 1) / R \cdot T 1 . T 2}$

$\log \mathrm{Q}_{10}=\frac{10 \times \operatorname{Ea} \times \log 2,718}{1,986 \times T 1 \times T 2}$

$\log \mathrm{Q}_{10}=\frac{10 \times 58449,966 \times \log 2,718}{1,986 \times(-15+273) \times(-5+273)}$

$\log \mathrm{Q}_{10}=1,848374$

$\mathrm{Q}_{10}=70,52998$

This value means that whenever there is an increase in temperature of $10^{\circ} \mathrm{C}$, the reaction rate increases by 70,529 , so the estimation of shelf life is based on the calculation of Q10 according to Table 7.

Table 7. Shelf life estimation with Q10

\begin{tabular}{|c|c|}
\hline Temperature $\left({ }^{\circ} \mathrm{C}\right)$ & Shelf life (days) \\
\hline-35 & 40,455 \\
\hline-25 & 36,096 \\
\hline $\mathbf{- 1 5}$ & $\mathbf{3 1 , 7 3 8}$ \\
\hline
\end{tabular}

\section{Conclusion}

Using the ASLT method through the Arrhenius approach, shelf life of spirulina ice cream at storage temperatures -15, 10 , and $-5{ }^{\circ} \mathrm{C}$ respectively 25,40 days, 24,13 days, and 21,20 days. During storage, longer storage increased physical damage, unstable emulsion system and dropped antioxidant capacity.

\section{References}

1. AOAC. AOAC Official Method 256.23. Emulsion Stability. (2000)

2. Asiah, N., L. Cempaka, dan W. David. Pendugaan Umur Simpan Produk Pangan. UB Press. Jakarta. (2018)

3. Baba, A.S., dan S. Amirdivani. Food Science and Technology. 44 (2011).

4. Barus, D.A. Fakultas Pertanian. Institut Pertanian Bogor. Thesis (2013)

5. Buck, J. S., C.E. Walker, dan M. M. Poerce. J. Food Sci. 51. 489 (1986)

6. Budiardi, T., N.B.P. Utomo, dan A. Santosa. Jurnal Akuakultur Indonesia. 9(2): 146-156 (2010)

7. Fu, B., dan T.P. Labuza. Foods. Springer. Boston, MA.( . 2000.)

8. Goff, H.D. J. Dairy Technology. Australia (2000)

9. Harris, H., dan M. Fadli. Jurnal Saintek Perikanan. 9(2): 53-62 (2014)

10. Julyta, R. Fakultas Perikanan dan Kelautan. Institut Pertanian Bogor. Thesis (2017)

11. Listyowati, T. Fakultas Pertanian. Universitas Gadjah Mada. Thesis (2017)

12. Madina, N. Fakultas Perikanan dan Ilmu Kelautan. Institut Pertanian Bogor. Thesis (2012).

13. Malik, P.,dan A. Paul. International Journal Of Food And Nutritional Sciences. 1(2): 44-50 (2013) 
14. Nagaraj, S., P. Arulmurugan, K. Karuppasamy, K.R. Jayappriyan, R. Sundararaj, N. Vijayanand, dan R. Rengasamy. J. Cancer Res. 4 (2): 29-34 (2011).

15. Negara, H.P., Y.B. Iwan, dan E. Nurfitri. J. Fish. Sci.. 16: 17 - 28 (2014)

16. O'sullivan, A.M.N. National University of Ireland. Philosophy in Food and Nutritional Sciences. Thesis (2013)

17. Oktavianto, I. T. Fakultas Pertanian, Universitas Gadjah Mada. Skripsi (2016)

18. Olivia, Y. T. Pengaruh Penambahan Spirulina platensis pada Roti Tawar Berbahan Dasar Terigu dan Tapioka Terhadap Tingkat Penerimaan Konsumen. Fakultas Pertanian. Universitas Gadjah Mada. Skripsi (2010)

19. Salim, A.C. Produk “Spirulmie”, Mie Instan Kaya Gizi dengan Penambahan Spirulina plantesis. Prodi Teknologi Pangan Unika Soegijapranata. Skripsi (2014)

20. Sari, O.F. Fakultas Perikanan dan Ilmu Kelautan Institut Pertanian Bogor. Skripsi (2013)

21. Shahbazizadeh, S., Kianoush K. D, dan S. Sara. Annual Research \& Review in Biology. 7: 144-154 (2015)

22. Sugiharto,E., dan F. Ayustaningwarno. Journal of Nutrition College. 3(4): 911-917 (2014)

23. Triana, R.N. Sekolah Pascasarjana. Institut Teknologi Bogor. Thesis (2014)

24. Yoga, I.B.K.W. Prosiding Seminar Nasional "Seminar Nasional FMIPA UNDIKSHA V Tahun 2015". Denpasar (2015)

25. Yuthana, P., dan P. Suppakul. Elsevier. 1-8 (2016) 